\title{
An Empirical Study on Youth's Preference for Social Networking
} Sites

\author{
Sabita Mahapatra ${ }^{1}$ \\ ${ }^{1}$ Marketing, Indian Institute of Management Indore, MP, India \\ Correspondence: Sabita Mahapatra, Marketing, Indian Institute of Management Indore, Rau, Pithampur Road, \\ Indore 453556, MP, India. Tel: 073-1243-9533. E-mail: sabita@iimidr.ac.in
}

Received: January 21, 2016

Accepted: February 2, 2016

Online Published: March 15, 2016

doi:10.5539/ijbm.v11n4p274

URL: http://dx.doi.org/10.5539/ijbm.v11n4p274

\begin{abstract}
Internet has dramatically transformed the way present generation youth interact with one another. The usage of social networking sites is increasing drastically among urban youth in India. Ironically online behaviour among youth as an area of research is understudied. The purpose of this paper was to explore the perception, preference and usage of social network sites among the young population. The data was collected by a self-administered questionnaire through personal survey. Data analysis revealed respondents' perception and preference for various social networking sites on parameters categorized as functional dimension and association dimension. The finding of the study provides useful insights for web designers regarding web features, design and content that would increase usage and preference. The research finding provides suggestions and directions for making social networking sites attractive, unique, engaging and user's friendly.
\end{abstract}

Keywords: social networks sites, youth, usage, preference, perception, India

\section{Introduction}

Social networking site as the major source of interaction in the world (Wright \& Hinson, 2009) has become an integral part of life for today's youth that has changed their way of communication. Social networking sites are classified into multimedia, communication and entertainment (Boyd \& Ellison, 2007). These sites give an opportunity to express oneself and collaborate with other (Buckingham, 2008). The term social network for some researchers means socially interactive technologies or networks that offer fast-paced, inexpensive, online communication (Bryant et al., 2006). By 2017, social network audience in the world will account for 2.55 billion as per eMarketer report of 'Worldwide Social Network Users: 2013 Forecast and Comparative Estimates'. India in specific had 54.8 million social network users in 2011 that is expected to increase to 282.9 million by 2017 . With approximately 150 million Internet users, India ranks 3rd in the world after China and US with 575 million and 275 million internet users respectively.

Internet has enabled millions of individuals (Pempek et al., 2009; Trusov et al., 2010), around the globe particularly the so-called "Generation M" (Vie, 2008) with a new form of communication (Ellison et al., 2007; Shin, 2010). Social network sites such as Facebook, MySpace, LinkedIn, and Orkut, are witnessing a rapid growth in recent past (Zhou, 2011) due to simplicity and convenience (Takemura \& Umino, 2009). Youth are the most frequent users of networking sites (Mason et al., 2010; Quillian \& Redd, 2009; Subrahmanyam et al., 2009; Gemmill \& Peterson, 2006), as compared to previous generation (English \& Duncan-Howell, 2008).

Numerous studied have been carried out on type and quality of activities conducted on social media networks. Chang and Cheng (2004) found unlike offline; online relationships are characterized as less intense in terms of the depth but more spread out in terms of width. Research findings have reported unwillingness to interact face to face resulting in use of social media networks (Sheldon et al., 2009). Youth and adults differ in their usage, evaluation and preference for social networking sites. They enjoy more independence and invest more time in experimenting and taking risk. Internet provides them scope to experiment with their identities.

Sites that provide a place to connect, understand and explore do compete with each other for attracting traffic. Site that provides opportunity to discover new things, to experiment with one's own self-image seems to be more preferred as they provide scope to try out and experiment new things (King, 2009). They act as an enabler in creating one's identity and in facilitating the socialization process (Urista et al., 2009). Social networking sites, 
provides opportunity for group formation, communication and exerting influence (Kane, Fichman, Gallaugher, \& Glaser, 2009; Pfeil, Arjan, \& Zaphiris, 2009; Ross et al., 2009), for sharing (Boyd \& Ellison, 2008; Pfeil et al., 2009; Powell, 2009; Tapscott, 2008), developing and maintain relationships (Ellison, Steinfield, \& Lampe, 2007; Kane et al., 2009). Individuals feel enabled to socialize and construct their own identity (Urista et al., 2009). These sites have changed the fulcrum of entertainment and information gathering hence researchers need greater insight on usage of online sites (West et al., 2007).

\section{Literature Review}

According to uses and gratifications approach motivation for usage of a specific social network is guided by social, psychological and other gratifications reasons (Sheldon et al., 2009). Any site that satisfies these specific needs stands higher chance for been preferred over other social network sites. McQuail (1995) summarized the needs and gratifications into four basic categories: diversion to escape from routines and daily problems, personal relationships, for companionship, personal identity, for reinforcing individual values, and finally for collecting needed information (West et al., 2007, pp. 428-429). Research (Roy, 2009) on use and gratification theory grouped media gratifications into two categories: process gratification associated with performance of the activity or usage of the medium and content gratifications associated with the information acquired (Kayahara \& Wellman, 2007).

Davis et al. (1992) found usefulness and enjoyment factors affected the usage of technology (Kim et al., 2007; Lin \& Bhattacherjee, 2008; Lu \& Su, 2009; Moon \& Kim, 2001; Teo et al., 1999; Van der Heijden, 2004). A user of social network values the effectiveness of the site in allowing him/her to form profiles, build and maintain relationships and in reaching out to others (Li \& Bernoff, 2008; Pfeil et al., 2009). Some scholars (Kang \& Lee, 2010; Kwon \& Wen, 2010; Sledgianowski \& Kulviwat, 2009) in their study found users' perceived usefulness of social network sites affected their intention of usage. Researchers (Gandal, 1994; Shurmer, 1993) found sites with complementary items or services enhanced continuous usage intention (Powell, 2009; Tapscott, 2008). Greater numbers of peers in network sites facilitates bigger network thereby creating a greater sense of pleasure (Powell, 2009; Tapscott, 2008) and enjoyment (Li \& Bernoff, 2008; Powell, 2009; Tapscott, 2008). Features like blogging, grouping, networking, instant messaging, enhanced social networking site interactions (Hsiao, 2011; Li, 2011; Wang et al., 2010).

Nyland and Near (2007) found entertainment, relationships and learning as the most common use of social networking sites. Ellison et al. (2007), in their study found that social networking sites were used by students primarily to maintain or intensify relationships. Stafford et al. (2004) identify content, process and social gratifications as the reason for usage of networking sites. Rafaeli (1986) in his study identifies entertainment, recreation and fun as the motive for usage of social networking sites. Subsequently Eighmey (1997) identified personal development, ease of use, relaxation and exchange of experiences as the motivating factor. Non-utilitarian motives like fun, escapism and spontaneity played an important role for usage of online social sites (Kim, 2002; Mathwick et al., 2002). Men and women with equal presence online had different motive for online use (Hoy \& Milne, 2010). More specifically, women exhibited greater concerns for privacy (Tufekci, 2008), and exhibited greater inclination for textured types of communication (Anick, 2005; Jackson et al., 2001). According to Nazir et al. (2008), the probability of a new user subscribing to an application is dependent on the network effects. Effectiveness of the site to build and maintain relationships helps to form a positive impression about the site (Li \& Bernoff, 2008; Pfeil et al., 2009). Scholars (Kang \& Lee, 2010; Kwon \& Wen, 2010; Sledgianowski \& Kulviwat, 2009) were of the opinion that perceived usefulness of social network sites affects usage intention. Kang \& Lee, 2010; Sledgianowski \& Kulviwat, 2009 viewed social network sites as a 'pleasure-oriented information system'. Researchers (Gandal, 1994; Shurmer, 1993) have pointed out the complementary services enhances usage intention (Powell, 2009; Tapscott, 2008). A sense of pleasure (Powell, 2009; Tapscott, 2008) and enjoyment (Li \& Bernoff, 2008; Powell, 2009; Tapscott, 2008) makes social networking sites unique. The essential features of social networking sites like blogging, grouping, networking and instant messaging enhances social interaction (Hsiao, 2011; Li, 2011; Wang et al., 2010). An understanding of gender differentials in terms of usage patterns seems to be extremely important (Li \& Kirkup, 2007). Most of the findings are source of debate, more so in Indian context hence it is important to have an insight on the usage, perception and preference for social networking sites among youth. Though a lot of studies have been done on the usage motive but rarely any research has been done on preference for social networking site which seems to be extremely needed for providing web designers insight for attracting traffic. Research study reveals that youngsters use social networking sites to connect with people who are not in close physical proximity to fulfill their affiliations need (Lee, 2013). Research studies have observed men use social networking sites for developing new relationships while women use for relationship maintenance (Muscanell \& Guadagno, 2012). 


\section{Research Methodology}

The present study addressed the following research questions:

Q 1: Why do youth prefer a particular social networking site?

Q 2: What are the main reasons for usage of a particular social network site?

Q 3: What are factors that influence the popularity of a particular social network site?

The empirical study was carried in Delhi the capital of India and the world's $2^{\text {nd }}$ largest urban conglomerate. Data was collected from 150 university students from 10 different undergraduate and graduate schools. Purposive sampling was used to collect data from youth above 19 years of age for the present study. This age group is expected to be active, independent and mature (McNeal, 1992), as by the age of 19 a child has already developed highly cognitive skill in choice making (Belk et al., 1982) and differentiating products and brands (Ward et al., 1977). The college students were considered to be the most appropriate respondents for the present study due to their exposure to internet and group influence (Arrington, 2005; Basil, 1996). The present study used survey method to collect data. The questionnaire consisted of 40 questions. The first part of the questionnaire was on demographic profile like age, gender, etc. The second part of the questionnaire dealt with questions measuring user's usage and preference for social networking site. The third part captured users perception based on the similarity and dissimilarity across various social networking site. Respondents were asked to compare 5 social networking sites, two sites at a time based on overall similarity and dissimilarity. The wording of the questionnaire was refined based on pretests. Out of the 150 only 124 responses received were found to be useful and 26 responses were discarded due to incomplete information. The Statistical Package for Social Sciences 18.0 (SPSS) was used for data analysis. The top 5 popular site were considered for the current study.

\section{Analysis and Findings}

From table 1 it was found that on an average more than $50 \%$ of the respondents used social networking site for about 5 hour per week. Table 2 reflects that majority of the respondents used social networking site for both personal and social purpose.

Table 1. Average time spent on social website weekly

\begin{tabular}{ll}
\hline Social networking Site & \% of Response \\
\hline Less than 5 hour & 58.2 \\
$5-10$ hours & 31.5 \\
$10-15$ hours & 7.6 \\
More than 15 hours & 2.7 \\
\hline
\end{tabular}

Table 2. Usage of social networking site

\begin{tabular}{lll}
\hline Usage of Social networking site & Mean & SD \\
\hline To see what others are doing & 3.30 & 1.14 \\
To post information & 2.77 & 1.07 \\
To obtain information about products & 3.60 & 1.28 \\
To find new market trends & 3.73 & 1.31 \\
For job alerts & 3.72 & 1.35 \\
To find organization services & 3.81 & 1.24 \\
To chat & 2.08 & 1.09 \\
To make friends & 2.49 & 1.14 \\
To play games & 3.76 & 1.30 \\
\hline
\end{tabular}

The internal consistency and reliability was measured using Cronbach Alpha and KMO (Kaiser-Meyer-Olkin Measure of Adequacy) tests. The instrument was reliable with an alpha value of 0.78 as shown in table 3 (Malhotra, 2003). 
Table 3. Reliability statistics

\begin{tabular}{ll}
\hline Cronbach's Alpha & N of Items \\
\hline 0.787 & 48 \\
\hline
\end{tabular}

Chi-square test was carried to find out the significant difference between the types of games played across different age groups in a particular networking site. From figure 1 it is evident that respondents played games extensively on Facebook.

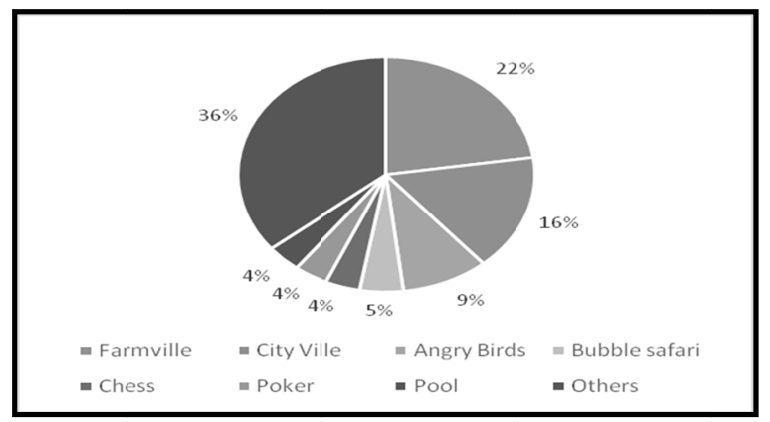

Figure 1. Games played in social website

Significant difference across gender group was found regarding information that respondents were reluctant to share on social networking sites. It was found that female respondents were reluctant to share their mobile number on the site. Table- 4 reflects the alpha value as 0.00 at 0.05 level of significance.

Table 4. Results of the Chi-Square test

\begin{tabular}{llll}
\hline & Value & Df & $\begin{array}{l}\text { Asymp. Sig. } \\
\text { (2-sided) }\end{array}$ \\
\hline Pearson Chi-Square & 16.202 & 2 & 0.000 \\
Likelihood Ratio & 16.097 & 2 & 0.000 \\
Linear-by-Linear Association & 16.012 & 1 & 0.000 \\
\hline
\end{tabular}

More than $60 \%$ respondent preferred Facebook as the most preferred site. Respondent's perception for different social networking site was found using multidimensional scale. Respondents were asked to rate various combinations of social networking site on a 10-point scale. Respondents rated two social networking sites at the same time based on overall similarity or dissimilarity. Respondents gave higher rating for a social networking site that they considered were similar and lower rating for a social networking site based on the perceived dissimilarity. Multidimensional scale was used to create a perceptual map for various social networking sites.

From figure-1 it is quite clear that Facebook, Twitter and Orkut occupied a position distinct from LinkedIn and MySpace on two dimensions. The dimension on horizontal axis in figure-1 was named as functional association and the dimension on the vertical axis was named as group association. The functional association dimension indicated the features of a social networking site like the type, variety, relevance and flexibility of features while group association dimension indicated the type of group (professional or personal), size of group (number of contacts) and group activity. Based on the dimension it was found that Facebook, Orkut and Twitter occupied somewhat similar position on both the dimension indicating the fact that these sites enjoyed a somewhat similar perception and hence emerged as strong competitor to each other.

From the perceptual map obtained from multidimensional scale, it is observed that Facebook, Orkut and Twitter are relatively high on both the parameter and enjoy different perception space compared to MySpace and LinkedIn. These sites occupied a position at a significantly different zone on the perceptual map.

While comparing with social networks as MySpace, Facebook seems to be highly private, with a member only policy. MySpace was perceived as provider of videos, music and picture. Facebook was perceived as user 
friendly in terms of its features which made it easy to locate and find things of interest. In addition, because of its highly customized nature, as well as with the feature of experimenting with self-image (King, 2009) it is more for socializing and talking to friends about work. Facebook seems to be preferred for social reasons, though at times it is used for learning purposes (Madge et. al, 2009) as well. Tweeter was perceives as information network, LinkedIn was perceived as a professional network while Facebook was perceived as a social network. Facebook seems to be highly accessible and scalable in terms of communication.

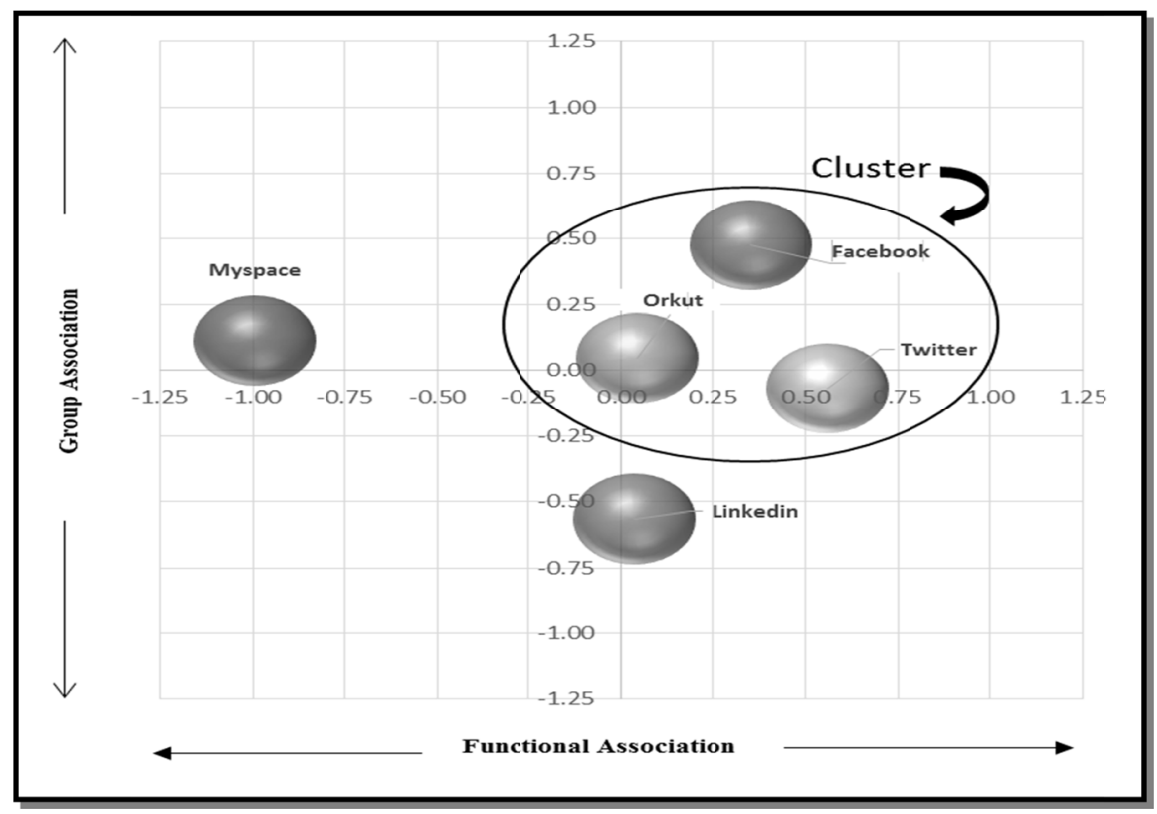

Figure 2. The relationship

\section{Conclusions}

The present paper provided insight on youth usage, perception and preference for social networking sites. First, the finding of the study concluded that features and type and number of members as the most important factor influencing perception and preference. The findings of the present study seems to be similar with Sledgianowski \& Kulviwat, (2009) study that suggested enjoyment and Powell (2009) and Tapscott (2008) study that suggested users experience of fun influencing user's preference for social networking site. Second, the study concluded type of group (professional or personal), size of group (number of contacts) and group activity to be important factor influencing perception and preference for social networking sites. This finding seems in line with the research study (Li \& Bernoff, 2008; Powell, 2009; Sledgianowski \& Kulviwat, 2009; Tapscott, 2008) that concluded that opportunity to expand in terms of contact and activity as one of the major reason to prefer a social networking site.

\section{Managerial Implications}

The finding of the present study provides insight and recommend for social networking designers to develop specific applications as per the demands, to allure and encourage network externalities. To strengthen stickiness of a site, web designers should include element of novelty and pleasurable surprise. Practitioners should constantly include value added applications to reinforce enjoyment and use experience. In the coming years for any social networking site to be a winner in the rapidly evolving social networking space they need to crave a special and clear position that would fit best for their target group. Hence web designers need to be careful about the site physical look, the features and about the element of privacy and flexibility. Hence companies should try to explore different ways to deal with privacy concerns by empowering users with more control to mitigate privacy concerns. A social networking site that is able to project a distinct position would attract traffic and enjoy strong network. The company-created or third-party managed social networking sites should ensure the quality and user experience to encourage users to share information on popular sites. Social networking sites need to develop and update their services continuously to satisfy user's needs. Marketers can use social networking sites for mobilizing users to get engaged in social movement or activities, like engaging in social cause campaign and 
building brand community.

\section{References}

Anick, J. (2005). Study Shows Slight Differences in How Men and Women Use Internet. The Canadian Press. Retrieved from http://search.ebscohost.com/login.aspx?direct1/4true\&db1/4n5h\&AN1/4MYO411262082905\&site1/4eds-live

Arrington, M. (2005). 85\% of College Students Use Facebook. Tech Crunch. Retrieved from http://www.techcrunch.com/2005/09/07/85-of-college-students-use-acebook/

Basil, M. D. (1996). The Use of Student Samples in Communication Research. Journal of Broadcasting \& Electronic Media, 40, 431-440.

Belk, R. W., Bahn, K. D., \& Mayer, R. N. (1982). Developmental recognition of consumption symbolism. Journal of Consumer Research, 9, 4-17.

Boyd, D. M., \& Ellison, N. B. (2008). Social network sites: Definition, history, and scholarship. Journal of Computer-Mediated Communication, 13, 210-230.

Bryant, J. A., Ashley, S. J., \& Amber, M. K. S. (2006). Mining, Text Messaging, and Adolescent Social Networks. Journal of Computer Mediated Communication, 11, 577-592.

Buckingham, D. (2008). Youth, Identity, and Digital Media. John D. and Catherine T. MacArthur Foundation Series on Digital Media and Learning. Cambridge, MA: MIT Press.

Chang, D. K. S., \& Cheng, G. H. (2004). A comparison of Offline and Online Friendship qualities at Different Stages of Relationship Development. Journal of Social and Personal Relationships, 21(3), 305-320.

Davis, F. D., Bagozzi, R. P., \& Warshaw, P. R. (1992). Extrinsic and intrinsic motivation to use computers in the workplace. Journal of Applied Social Psychology, 22, 1111-1132.

Eighmey, J. (1997). Profiling user responses to commercial web sites. Journal of Advertising Research, 37(3), 59-66.

Ellison, N. B., Steinfield, C., \& Lampe, C. (2007). The benefits of Facebook "friends": Social capital and college students' use of online social network sites. Journal of Computer-Mediated Communication, 12, 1143-1168.

English, R. M., \& Duncan-Howell, J. A. (2008). Facebook goes to college: using social networking tools to support students undertaking teaching practicum. Journal of Online Learning and Teaching, 4(4), 596-601.

Gandal, N. (1994). Hedonic price indexes for spreadsheets and an empirical-test for network externalities. Journal of Economics, 25, 160-170.

Gemmill, E., \& Peterson, M. (2006). Technology use among college students: implications for student affairs professionals. NASPA Journal, 43(2), 280-300.

Hoy, M. G., \& Milne, G. (2010). Gender differences in privacy-related measures for young adult Facebook users. Journal of Interactive Advertising, 10(2), 28-45.

Hsiao, K. (2011). Why are internet users willing to pay for social networking services? Online Information Review, 35(5), 770-88.

Jackson, L. A., Ervin, K. S., Gardner, P. D., \& Schmitt, N. (2001). Gender and the internet: women communicating and men searching. Sex Roles, 44(5/6), 363-379.

Kane, G. C., Fichman, R. G., Gallaugher, J., \& Glaser, J. (2009). Community relations 2.0. Harvard Business Review, 87, 45-50.

Kang, Y. S., \& Lee, H. (2010). Understanding the role of an IT artifact in online service continuance: An extended perspective of user satisfaction. Computers in Human Behavior, 26, 353-364.

Kayahara, K., \& Wellman, B. (2007). Searching for Culture-high and low. Journal of Computer-Mediated Communication, 12(3), 824-845.

Kim, E., \& Lee, B. (2007). An economic analysis of customer selection and leveraging strategies in a market where network externalities exist. Decision Support Systems, 44, 124-134.

Kim, Y. (2002). Consumer value: An application to mall and internet shopping. International Journal of Retail and Distribution Management, 30(12), 595-602. 
King, T. (2009). Teens' Use of Online Social Networks. Journal of New Communications Research, 4(2), 36-41.

Kwon, O., \& Wen, Y. (2010). An empirical study of the factors affecting social network service use. Computers in Human Behavior, 26, 254-263.

Lee, D. (2013). The role of attachment style in building social capital from a social networking site: The interplay of anxiety and avoidance. Computers in Human Behavior, 29(4), 1499-1509. http://dx.doi.org/10.1016/j.chb.2013.01.012

Li, C., \& Bernoff, J. (2008). Groundswell: Winning in a world transformed by social technologies. Boston, MA: Harvard Business School Press.

Li, D. (2011). Online social network acceptance: A social perspective. Internet Research, 21(5), 562-80.

Li, N., \& Kirkup, G. (2007). Gender and cultural differences in internet use: A study of China and the UK. Computers \& Education, 48(2), 301-317.

Lin, C. P., \& Bhattacherjee, A. (2008). Understanding online social support and its antecedents: A socio-cognitive model. The Social Science Journal, 46, 724-737.

Lu, H. P., \& Su, Y. J. P. (2009). Factors affecting purchase intention on mobile shopping web sites. Internet Research, 19, 442-458.

Madge, C., Julia, M. J. W., \& Tristram, H. (2009). Facebook, social Integration and Informal Learning at University: It is more for Socializing and Talking to Friends about Work Than for Actually Doing Work. Learning, Media and Technology, 34(2), 141-155.

Malhotra, K. N. (2003). Marketing Research an Applied Orientation (3rd ed.). Pearson Education.

Mason, M. J., Valente, T. W., Coatsworth, J. D., Mennis, J., Lawrence, F., \& Zelenak, P. (2010). Place-based social network quality and correlates of substance use among urban adolescents. Journal of Adolescence, 33(3), 419-427.

Mathwick, C., Malhotra, N., \& Rigdon, E. (2002). The effect of dynamic retail experiences on experiential perceptions of value: an internet and catalog comparison. Journal of Retailing, 78(1), 51-60.

McNeal, J. U. (1992). Kids as Customers: A Handbook of Marketing to Children. Lexington Books, Oxford.

McQuail, D. (1995). Mass Communication Theory. Newbury Park, CA: Sage.

Moon, J. W., \& Kim, Y. G. (2001). Extending the TAM for a World-Wide-Web context. Information \& Management, 38, 217-230.

Muscanell, N. L., \& Guadagno, R. E. (2012). Make new friends or keep the old: Gender and personality differences in social networking use. Computers in Human Behavior, 28(1), 107-112. http://dx.doi.org/10.1016/j.chb.2011.08.016

Nazir, A., Raza, S., \& Chuah, C. N. (2008). Unveiling Facebook: A measurement study of social network based applications. Proceedings of the ACM Internet Measurement Conference.

Nyland, R., \& Near, C. (2007). Jesus is my friend: Religiosity as a mediating factor in internet social networking use. Paper presented at AEJMC Midwinter Conference, Reno, NV, February.

Pempek, T. A., Yermolayeva, Y. A., \& Yermolayeva, S. L. (2009). College students' social networking experiences on Facebook. Journal of Applied Developmental Psychology, 30, 227-238.

Pfeil, U., Arjan, R., \& Zaphiris, P. (2009). Age differences in online social networking: A study of user profiles and the social capital divide among teenagers and older users in MySpace. Computers in Human Behaviour, $25,643-654$.

Powell, J. (2009). 33 Million people in the room: How to create, influence, and run a successful business with social networking. NJ: FT Press.

Quillian, L., \& Redd, R. (2009). The friendship networks of multiracial adolescents. Social Science Research, $38(2), 279-95$.

Rafaeli, S. (1986). The electronic bulletin board. A computer-driven mass-medium. Computers and the Social Sciences, 2(3), 23-31.

Ross, C., Orr, E. S., Sisic, M., Arseneault, J. M., Simmering, M. G., \& Orr, R. R. (2009). Personality and motivations associated with Facebook use. Computers in Human Behaviour, 25, 578-586. 
Roy, S. (2009). Internet uses and gratifications: A survey in the Indian context. Computers in Human Behaviour, 29, 878-886.

Sheldon, P., \& Honeycutt, J. (2009). Unwillingness to Communicate Impact on Motives for Facebook Use. International Communication Association, 1-27.

Shin, D. H. (2010). The effects of trust, security and privacy in social networking: A security-based approach to understand the pattern of adoption. Interacting with Computers, 22(5), 428-438.

Shurmer, M. (1993). An investigation into sources of network externalities in the packaged PC software market. Information Economics \& Policy, 5, 231-251.

Sledgianowski, D., \& Kulviwat, S. (2009). Using social network sites: The effects of playfulness, critical mass and trust in a hedonic context. Journal of Computer Information Systems, 49, 74-83.

Stafford, F., Stafford, R., \& Schkade, I. (2004). Determining uses and gratifications for the internet. Decision Sciences, 35(2), 259-288.

Subrahmanyam, K., Reich, S. M., Waechter, N., \& Espinoza, G. (2009). Online and offline social networks: Use of social networking sites by emerging adults. Journal of Applied Developmental Psychology, 29(6), 420-433.

Takemura, T., \& Umino, A. (2009). A quantitative study on Japanese internet users' awareness to information security: Necessity and importance of education and policy. Proceedings of World Academy of Science: Engineering \& Technology, 60, 638-644.

Tapscott, D. (2008). Grown up digital: How the next generation is changing your world. New York: McGraw-Hill.

Teo, T. S. H., Lim, V. K. G. \& Lai, R. Y. C. (1999). Intrinsic and extrinsic motivation in Internet usage. Omega: International Journal of Management Science, 27, 25-37.

Trusov, M., Bodapati, A. V., \& Bucklin, R. E. (2010). Determining influential users in internet social networks. Journal of Marketing Research, 47(4), 643-658.

Tufekci, Z. (2008). Can you see me now? Audience and disclosure regulation in online social network sites. Bulletin of Science. Technology \& Society, 28(1), 20-36.

Urista, M. A., Qingwen, D., \& Day, K. D. (2009). Explaining Why Young Adults Use MySpace and Facebook Through Uses and Gratifications Theory. Human Communication, 12(2), 215-229.

Van der Heijden, H. (2004). User acceptance of hedonic information systems. MIS Quarterly, 28, 695-704.

Vie, S. (2008). Digital divide 2.0: 'Generation $\mathrm{M}$ ' and online social networking sites in the composition classroom. Computers \& Composition, 25(1), 9-23.

Wang, C. C., \& Chang, Y. T. (2010). Cyber relationship motives: Scale development and validation. Social Behavior and Personality, 38(3), 289-300.

Ward, S., Wackman, D. B., \& Wartella, E. (1977). How Children Learn To Buy: The Development of Consumer Information Processing Skills. Sage, Beverly Hills, CA.

West, R., \& Lynn, H. T. (2007). Introducing Communication Theory, Analysis and Application (3rd ed.). McGraw Hill.

Wright, D., \& Hinson, M. (2009). An Updated Look at the Impact of Social Media on Public Relations Practice. Public Relations Journal, 3(2), 27.

Zhou, T. (2011). Understanding online community user participation: a social influence perspective. Internet Research, 21(1), 67-81.

\section{Copyrights}

Copyright for this article is retained by the author(s), with first publication rights granted to the journal.

This is an open-access article distributed under the terms and conditions of the Creative Commons Attribution license (http://creativecommons.org/licenses/by/3.0/). 